\title{
The Influence of Chankanay Zeolites as Feed Additives on the Chemical, Biochemical and Histological Profile of the Rainbow Trout (Oncorhynchus mykiss)
}

\author{
Assel Paritova1, Nurzhan Sarsembayeva1, Bożena Łozowicka ${ }^{2 *}$, Amangeldy Maulanov ${ }^{3}$, Gulnur Kuzembekova ${ }^{1}$, Aida Abzhalieva ${ }^{1}$ and Piotr \\ Kaczyński² \\ ${ }^{1}$ Department of Veterinary Sanitary Examination and Hygiene, Kazakh National Agrarian University, Abaya 8, 050010 Almaty, Kazakhstan \\ 2Institute of Plant Protection - National Research Institute, Chelmonskiego 22, 15-195 Bialystok, Poland \\ ${ }^{3}$ Department of Biological Safety, Kazakh National Agrarian University, Abaya 8, 050010 Almaty, Kazakhstan
}

\begin{abstract}
This article presents the results of the influence of zeolites as feed additives on the chemical, biochemical and histological profile of fish. Research was conducted for 63 days using a rainbow trout from Turgen village (Kazakhstan). The studied material was zeolitic tuff from the Chankanay deposit as an additive to RGM-2M feed. The fish were fed with a normal diet, and the diet supplemented with $1 \%, 2 \%, 3 \%$ and $4 \%$ of natural zeolites. Pathomorphological and histological examinations of muscle tissues and internal organs of the rainbow trout were carried out. Additionally, lipid contents, FAs compositions and amino acid compositions were studied. The content of essential amino acids and proportion of essential amino acids to non-essential amino acids in the experimental group was higher than in the control group. Zeolite supplementation at the $4 \%$ inclusion level showed a high content of the amino acids. The results of this study confirmed that zeolites had a positive effect on the chemical, amino acid and fatty acid composition. The addition of natural zeolites to the feed does not cause pathological changes in the liver, muscles and other organs of the experimental fish, and no other negative effects were determined.
\end{abstract}

Keywords: Zeolite; Feed additives; Oncorhynchus mykiss; Kazakhs farm; Chemical composition

\section{Introduction}

Since the original discovery of zeolitic minerals in volcanogenic sedimentary rock, zeolitic tuffs have been found in many areas of the world. In past decades, natural zeolites have found a variety of applications in adsorption, catalysis, the building industry, agriculture, soil remediation, and energy $[1,2]$.

A number of studies have considered the use of zeolites in veterinary medicine. Zeolite supplemented diets are well tolerated by animals; they support biomass production and improve the health status of the animals [3,4]. Malymin [5] studied the effect of impurities introduced into the diet of cows (the zeolite and humus coal) on the mineral and protein metabolism and on the parturition process. In other papers, Yarovan [6] showed the possibility of using natural zeolites from Khonyn in order to prevent the development of oxidative stress, to cure disorders in the antioxidant system of cows, and to treat diseases of the reproductive system during unfavourable maintenance conditions and the winter-stall feeding period. The list of reports on the use of the zeolites in the feed for birds has been updated [7-19].

Clinoptilolite in the diet for layer hens $(50 \mathrm{~g} / \mathrm{kg})$ increased the numbers of laid eggs, stability of eggshell and efficiency of food utilisation. However, neither the onset of the egg laying cycle, nor the egg weight were affected [10]. Moreover, the zeolite supplementation of the diets with high contents of cholesterol exerts a hypocholesterolemic effect [20].

Kuramshina et al. [21] assess the effect of zeolites from Baimak and Sibai deposits added in the amount of $3 \%$ weight of chicken feed. The experimental group compared to the control group showed a significant increase of red and white blood cells, and hemoglobin. In the experimental group, egg yolks exhibited an increase of carotene, and vitamins A and B2 compared to the control group. Zedgenizova and Prosekina [13] also reported positive results of the experiments in which the zeolites were added to the chicken feed. In particular, when the zeolites were added in the amount of $5 \%$ weight of the feed, there was an increase of red and white blood cells, and hemoglobin. The feed additive also increased body weight without causing a negative impact on the overall condition of hens.

Lumbunov et al. [17] showed that zeolites with a particle size of 0.5-2.5 mm were good mineral supplements for adult birds. Their addition to the feed of hens (Sotnikovskoe poultry farm) in the amount of $3.6 \%$ increased egg production by $5-8 \%$ and improved egg shell quality. Furthermore, the use of the zeolites had a notable deodorizing effect. Similarly, such results were also found by Khaustov and Shadrin et al. [22]

Polyakov et al. $[23,24]$ published a number of articles on the use of zeolites in the fisheries sector. One of their experiments showed comprehensively the studied patterns of nitrate and nitrite accumulation in water and fish products as well as ways of reducing their toxicity by means of the zeolites.

Studies that tested the zeolites in fish husbandry have shown the possibility of their successful use as feed additives. There is a possibility that the use of the zeolites and zeolite - type aluminum silicates can have a significant positive effect on the fish that consume them. The

*Corresponding author: Bożena Łozowicka, Institute of Plant Protection National Research Institute, Chelmonskiego 22, 15-195 Bialystok, Poland, Tel: +48 8567854 70; Fax: +48 8567534 19; E-mail: B.Lozowicka@iorpib.poznan.pl

Received October 22, 2013; Accepted November 28, 2013; Published December 12, 2013

Citation: Paritova A, Sarsembayeva N, Łozowicka B, Maulanov A, Kuzembekova $G$, et al. (2013) The Influence of Chankanay Zeolites as Feed Additives on the Chemical, Biochemical and Histological Profile of the Rainbow Trout (Oncorhynchus mykiss). J Aquac Res Development 5: 205 doi:10.4172/2155-9546.1000205

Copyright: (c) 2013 Paritova A, et al. This is an open-access article distributed under the terms of the Creative Commons Attribution License, which permits unrestricted use, distribution, and reproduction in any medium, provided the original author and source are credited. 
Citation: Paritova A, Sarsembayeva N, Łozowicka B, Maulanov A, Kuzembekova G, et al. (2013) The Influence of Chankanay Zeolites as Feed Additives on the Chemical, Biochemical and Histological Profile of the Rainbow Trout (Oncorhynchus mykiss). J Aquac Res Development 5: 205 doi:10.4172/2155-9546.1000205

Page 2 of 8

addition of a natural zeolite of the clinoptilolite type to feed mixtures in low doses of about $1-2 \%$ has an influence on very important functions that have heretofore not been recorded for other natural compounds $[25,26]$. The addition of clinoptilolite to the feed is assumed to have a similar effect to that of antibiotics.

The fish are regarded to be a valuable source of animal protein and fat in human diets. It is known to be a source of protein that is rich in essential amino acids (isoleucyne, lysine, methionine, cysteine, threonine, and tryptophan). Omega- 3 and omega- 6 fatty acids (FAs), are essential compounds in fish lipids. These compounds play an important role in human nutrition and health promotion. The amount of amino acid and fatty acid content in the fish can be changed by diet.

Previously performed studies in this area can be characterized as fragmented and as not providing enough information to substantiate the use of tuff - type zeolites in the fish feed. Therefore, we were conducted research with the aim of defining the efficiency of using the zeolites as feed additives.

In general, the purpose of the research was to examine the influence of the feed additives containing the zeolites from the Chankanay (Kazakhstan) deposits on a rainbow trout.

The main goals of research were as follows. Firstly, it was to assess the effects of zeolite feed additives on the pathomorphological and histological status of the muscle tissue and internal organs of a rainbow trout (Oncorhynchus mykiss). Secondly, it aimed at analyzing the chemical and biochemical composition of the fish meat.

\section{Materials and Methods}

Investigations were carried out at the Department of VeterinarySanitary Examination and Hygiene, at the Kazakhstan-Japan Center of the Kazakh National Agrarian University and at the trout farm in Turgen village during 2011-2013 years.

The material of study was the zeolitic tuff of Chankanay deposit (Kazakhstan, Almaty region, Figure 1). Chemical composition (\%) of using zeolite: $\mathrm{SiO} 2$ - 55.90, $\mathrm{Al} 2 \mathrm{O} 3$ - 15.60, $\mathrm{Fe} 2 \mathrm{O} 3$ - 5.90, $\mathrm{CaO}$ - 5.57, $\mathrm{MgO}-2.54, \mathrm{Na} 2 \mathrm{O}-3.05, \mathrm{~K} 2 \mathrm{O}-2.15, \mathrm{TiO} 2-0.45$.

For research was used feed by recipes of RGM-2M: fishmeal -

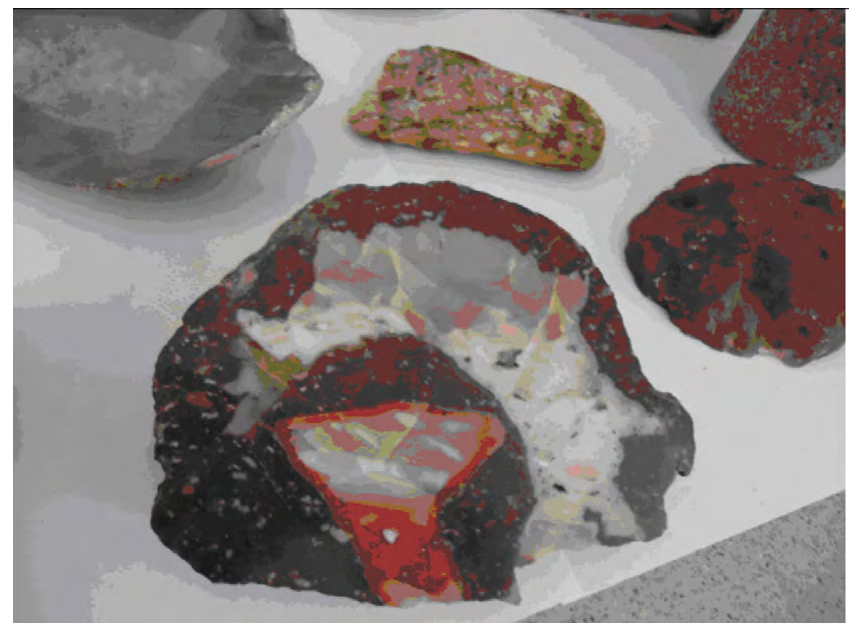

Figure 1: Natural zeolite from Chankanay deposits (Kazakhstan, Almaty region).
$4.6 \%$, meat and bone - $9 \%$, blood - $5 \%$, wheat - $11 \%$, algal - $1 \%$, hay - $2 \%$, reverse dry - $9 \%$, yeast hydrolysis - $4 \%$, soybean meal (flour) $6 \%$, sunflower meal (flour) - $2 \%$, fish oil (vegetable oil) - $4 \%$, premix - $1 \%$. The fish fed 6-8 times a day.

In the first batch of experimental feed, $1 \%, 2 \%, 3 \%$ and $4 \%$ zeolite content (grit particle size 0.01 to $1 \mathrm{~mm}$ in diameter) was introduced by replacing from $1 \%$ to $4 \%$ of feed, respectively.

Normal healthy Oncorhynchus mykiss $(n=300)$ were randomly divided into five groups. The studies were performed in triplicate. Tests were carried out for 63 days. The standard $10 \mathrm{~m} 3$ cages have been used for this purpose. Density of fish stock, feeding rations and other parts of their growing biotechnology were complied fish-breeding regulations for industrial fish farms. In each case age groups have been formed with fish that weren't significantly different from initial individual weight. Before and after the test all the fish in each cage were weighed, and in order to determine the average individual weight $20 \%$ of the weighted fish has been calculated. Decadal average temperature in cages ranged from $22.5-22.9^{\circ} \mathrm{C}$, dissolved oxygen content was between $7.91-8.54$ $\mathrm{mg} / \mathrm{l}$.

Sampling of fish meat was performed in compliance with GOST 23481 [27]. Fish were gutted, packed in ice and transported to the laboratory on the day of slaughter; all analyses were performed the next day. After being taken to the laboratory, fish were dissected and the liver, kidney and intestine of them were exposed.

Histological examination was carried out in accordance with GOST 19496 [28] and GOST R 51604 [29]. Intestine samples (proximal, middle and distal parts, liver and kidney) were fixed in $10 \%$ formalin solution. After fixation, the samples were rinsed in water, dehydrated in graded levels of 50\%,70\%, 90\%, 95\% and $100 \%$ ethyl alcohol for two minutes, cleared in xylene and embedded in paraffin. Dewaxed sections $(5-7 \mu \mathrm{m})$ were stained for histopathological purposes with hematoxylin and eosin (H\&E), periodic-acid Schiff (PAS) and Alcian blue ( $\mathrm{pH} 2.5)$ [30] and examined microscopically (Leica DM4000 B LED).

\section{Determination of chemical composition of fish meat}

Before analyses the fish fillets were minced with skin. Crude protein was determined by the Kieldahl procedure [31]. The moisture was determined by oven drying at $105^{\circ} \mathrm{C}$ until they reached a constant weight. Total fat was extracted with petroleum ether using the Soxhlet system. Ash was determined using a muffle furnace by heating at $550^{\circ} \mathrm{C}$ for $8 \mathrm{~h}$

Amino acid content was determined by ion exchange chromatography in an amino acid analyser (AAA-881 "Czechia" amino acid analyser). Prior to hydrolysis, samples were defatted with petroleum ether at room temperature. Acid hydrolysis $(6 \mathrm{~N} \mathrm{HCl})$ was performed at $110^{\circ} \mathrm{C}$ for $2 \mathrm{~h}$ for all amino acids except methionine and a sulphur-containing amino acid. Methionine was measured after oxidation with a performic acid followed by acid hydrolysis [31]. The Beckman Standard STD amino acid solution was used for calibration. The amounts of each amino acid were given as g per $100 \mathrm{~g}$ sample. All analyses were conducted with two fold repetition. The amino acid score was calculated according to $\mathrm{FAO} / \mathrm{WHO}$ [32].

\section{Fatty acids analysis of fish meat}

The fatty acid profile of trout samples was determined as fatty acid methyl esters (FAMEs). Prior to analysis, the head, tail, fins, and viscera of the fish were removed. The edible tissue was filleted with the skin left on and homogenized. Fish samples were prepared using direct 
Citation: Paritova A, Sarsembayeva N, Łozowicka B, Maulanov A, Kuzembekova G, et al. (2013) The Influence of Chankanay Zeolites as Feed Additives on the Chemical, Biochemical and Histological Profile of the Rainbow Trout (Oncorhynchus mykiss). J Aquac Res Development 5: 205 doi:10.4172/2155-9546.1000205

Page 3 of 8

saponification with $\mathrm{KOH} /$ methanol followed by a derivatization with (trimethylsilyl) diazomethane by the method of Aldai et al. [33].

FA composition was analyzed by GC Agilent with an autosampler (Agilent HP $6890 \mathrm{~N}$, USA) equipped with a flame ionization detector and a Supelco-SP-2330 fused silica capillary column $(30 \mathrm{~m}, 0.25 \mathrm{~mm}$ i.d., $0.20 \mathrm{~mm}$ film thickness of polyethylene glycol) (Bellefonte, PA). The oven temperature was $140{ }^{\circ} \mathrm{C}$, held at $5 \mathrm{~min}$, raised to $200^{\circ} \mathrm{C}$ at a rate of $4^{\circ} \mathrm{C} / \mathrm{min}$ and to $220^{\circ} \mathrm{C}$ at a rate of $1^{\circ} \mathrm{C} / \mathrm{min}$, while the injector and the detector temperature were set at $220^{\circ} \mathrm{C}$ and $280^{\circ} \mathrm{C}$, respectively. The sample size was $1 \mu \mathrm{l}$ and the carrier gas was controlled at $16 \mathrm{psi}$. The split used was 1:100. The individual FAMEs (fatty acid methyl esters) were identified according to similar peak retention times using standard mixture Supelco 37 Component FAME Mix.

All data were subjected to one-way variance analysis (ANOVA) using the Statistica 8.0 software environment to test the effects of the experimental diets. Duncan's multiple range test and critical ranges were used to test differences among the individual means. The differences were regarded as significant when $\mathrm{P}<0.05$. All of the results are expressed as the means \pm S.D.

\section{Results and Discussion}

Table 1 shows the results of lipid, protein, fat and ash concentrations in the muscle tissue of the fish in the control and experimental groups. The results of amino acid content in the meat are presented in Table 2. The fatty acid content in the fish is shown in Table 3.

\section{Histological analysis}

Histological analysis of the digestive system is considered to be a

\begin{tabular}{|c|c|c|c|c|c|}
\hline \multirow{2}{*}{$\begin{array}{c}\text { Parameter } \\
\text { Units of measurement }\end{array}$} & \multirow{2}{*}{$\begin{array}{l}\text { Control group } \\
(n=20)\end{array}$} & \multicolumn{4}{|c|}{$\begin{array}{l}\text { Experimental group } \\
(n=20)\end{array}$} \\
\hline & & $1 \%$ & $2 \%$ & $3 \%$ & $4 \%$ \\
\hline Proteins g/100g & $16.00 \pm 0.17^{a}$ & $16.7 \pm 0.32^{\mathrm{a}}$ & $17.08 \pm 0.54^{a}$ & $17.67 \pm 0.28^{a}$ & $18.73 \pm 0.36^{a}$ \\
\hline Lipids g/100g & $5.30 \pm 0.11^{b}$ & $5.40 \pm 0.14^{\mathrm{a}}$ & $5.35 \pm 0.11^{\mathrm{a}}$ & $5.45 \pm 0.10^{a}$ & $5.5 \pm 0.21^{\mathrm{a}}$ \\
\hline Moisture $\mathrm{g} / 100 \mathrm{~g}$ & $73.40 \pm 1.15^{\mathrm{a}}$ & $73.97 \pm 1.21^{\mathrm{b}}$ & $73.99 \pm 1.14^{b}$ & $73.85 \pm 1.64^{b}$ & $74.05 \pm 1.34^{b}$ \\
\hline Ash g/100g & $1.43 \pm 0.01^{c}$ & $1.43 \pm 0.87^{\mathrm{a}}$ & $1.44 \pm 0.24^{a}$ & $1.45 \pm 0.52^{\mathrm{a}}$ & $1.45 \pm 0.41^{\mathrm{a}}$ \\
\hline Digestibility (\%) & 98.57 & 98.67 & 98.77 & 98.57 & 97.65 \\
\hline Energy value kcal $/ 100 \mathrm{~g}$ & $112.00 \pm 2.61^{c}$ & $115.60 \pm 3.67^{c}$ & $113.35 \pm 4.14^{c}$ & $114.45 \pm 3.62^{c}$ & $115.28 \pm 4.25^{c}$ \\
\hline
\end{tabular}

Mean values of 20 samples \pm standard deviation. The letters in the same line show the differences in the results of statistical analysis.

Table 1: Chemical profile of the muscle tissue of rainbow trout (Trial groups: control and experimental).

\begin{tabular}{|c|c|c|c|c|c|c|}
\hline \multirow{2}{*}{ Amino acids } & \multirow{2}{*}{$\begin{array}{l}\text { Recommended daily intake } \\
\text { (g/70kg/body weight) }\end{array}$} & \multirow{2}{*}{ Control group } & \multicolumn{4}{|c|}{ Experimental group } \\
\hline & & & $1 \%$ zeolite & $2 \%$ zeolite & $3 \%$ zeolite & $4 \%$ zeolite \\
\hline Threonine & 0.46 & $0,72 \pm 0.03^{b}$ & $0,87 \pm 0.05^{b}$ & $0,86 \pm 0.04^{b}$ & $0,89 \pm 0.04^{b}$ & $0,95 \pm 0.06^{b}$ \\
\hline Valine & 0.80 & $0,89 \pm 0.07^{b}$ & $0,95 \pm 0.07^{\mathrm{b}}$ & $0,95 \pm 0.08^{b}$ & $0,99 \pm 0.06^{b}$ & $1,09 \pm 0.09^{b}$ \\
\hline Isoleucine & 1.1 & $0,80 \pm 0.12^{b}$ & $0,68 \pm 0.09^{b}$ & $0,71 \pm 0.07^{b}$ & $0,80 \pm 0.10^{\mathrm{b}}$ & $0,78 \pm 0.08^{b}$ \\
\hline Leucine & 0.67 & $1,69 \pm 0.21^{c}$ & $1,79 \pm 0.20^{\circ}$ & $1,87 \pm 0.18^{c}$ & $1,92 \pm 0.22^{\mathrm{c}}$ & $2,01 \pm 0.18^{c}$ \\
\hline Tyrosine & \multirow{2}{*}{0.85} & $0,54 \pm 0.12^{\mathrm{ab}}$ & $0,47 \pm 0.10^{\mathrm{a}}$ & $0,57 \pm 0.12^{\mathrm{ab}}$ & $0,54 \pm 0.15^{\mathrm{ab}}$ & $0,61 \pm 0.13^{\mathrm{ab}}$ \\
\hline Phenylalanine & & $0,89 \pm 0.05^{b}$ & $0,91 \pm 0.07^{b}$ & $0,99 \pm 0.08^{b}$ & $0,94 \pm 0.04^{b}$ & $1,01 \pm 0.07^{b}$ \\
\hline Cysteine & \multirow{2}{*}{0.85} & $0,25 \pm 0.02^{\mathrm{a}}$ & $0,27 \pm 0.01^{\mathrm{a}}$ & $0,29 \pm 0.02^{\mathrm{a}}$ & $0,31 \pm 0.02^{\mathrm{a}}$ & $0,33 \pm 0.03^{a}$ \\
\hline Methionine & & $0,45 \pm 0.04^{a}$ & $0,55 \pm 0.06^{a}$ & $0,52 \pm 0.07^{a}$ & $0,51 \pm 0.04^{a}$ & $0,55 \pm 0.07^{a}$ \\
\hline Tryptophan & 0.20 & $0,27 \pm 0.03^{a}$ & $0,18 \pm 0.01^{\mathrm{a}}$ & $0,21 \pm 0.02^{\mathrm{a}}$ & $0,27 \pm 0.03^{\mathrm{a}}$ & $0,21 \pm 0.02^{a}$ \\
\hline Lysine & 0.66 & $1,20 \pm 0.21^{c}$ & $1,40 \pm 0.22^{\mathrm{c}}$ & $1,40 \pm 0.18^{c}$ & $1,20 \pm 0.28^{c}$ & $1,40 \pm 0.19^{c}$ \\
\hline$\Sigma$ of exogenous amino acids EAA & 5.59 & 7,70 & 8,07 & 8,37 & 8,37 & 8,94 \\
\hline Aspartic acid & - & $1,05 \pm 0.21^{\mathrm{bc}}$ & $1,15 \pm 0.17^{\mathrm{bc}}$ & $1,25 \pm 0.23^{\mathrm{bc}}$ & $1,25 \pm 0.31^{\mathrm{bc}}$ & $1,15 \pm 0.28^{b c}$ \\
\hline Histidine & - & $0,56 \pm 0.17^{\mathrm{ab}}$ & $0,58 \pm 0.14^{\mathrm{ab}}$ & $0,65 \pm 0.12^{\mathrm{ab}}$ & $0,66 \pm 0.17^{\mathrm{ab}}$ & $0,65 \pm 0.11^{\mathrm{ab}}$ \\
\hline Arginine & - & $1,46 \pm 0.32^{c}$ & $1,50 \pm 0.38^{c}$ & $1,5 \pm 0.44^{c}$ & $1,46 \pm 0.28^{c}$ & $1,5 \pm 0.24^{c}$ \\
\hline Serine & - & $0,55 \pm 0.07^{a}$ & $0,45 \pm 0.08^{a}$ & $0,45 \pm 0.07^{a}$ & $0,55 \pm 0.05^{\mathrm{a}}$ & $0,45 \pm 0.04^{a}$ \\
\hline Glutamic acid & - & $3,05 \pm 0.23^{c}$ & $3,27 \pm 0.18^{c}$ & $3,28 \pm 0.19^{c}$ & $3,25 \pm 0.19^{c}$ & $3,28 \pm 0.21^{c}$ \\
\hline Proline & - & $0,57 \pm 0.04^{a}$ & $0,46 \pm 0.04^{a}$ & $0,46 \pm 0.04^{a}$ & $0,57 \pm 0.05^{\mathrm{a}}$ & $0,64 \pm 0.06^{a}$ \\
\hline Glycine & - & $0,82 \pm 0.08^{b}$ & $0,60 \pm 0.09^{\mathrm{ab}}$ & $0,60 \pm 0.10^{\mathrm{ab}}$ & $0,86 \pm 0.11^{\mathrm{b}}$ & $0,76 \pm 0.09^{b}$ \\
\hline Alanine & - & $0,94 \pm 0.09^{b}$ & $1.00 \pm 0.08^{b}$ & $1,11 \pm 0.12^{\mathrm{b}}$ & $0,94 \pm 0.10^{\mathrm{b}}$ & $1,26 \pm 0.13^{b}$ \\
\hline$\Sigma$ NEAA & - & 9 & 9,01 & 9,3 & 9,54 & 9,69 \\
\hline$\Sigma$ EAA/ $\Sigma$ NEAA & - & $0,86 \pm 0.06^{b}$ & $0,89 \pm 0.07^{b}$ & $0,90 \pm 0.06^{b}$ & $0,88 \pm 0.07^{b}$ & $0,92 \pm 0.08^{b}$ \\
\hline
\end{tabular}

Table 2: The amino acids compositions of rainbow trout (control and experimental groups, g/100 g muscle). 
Citation: Paritova A, Sarsembayeva N, Łozowicka B, Maulanov A, Kuzembekova G, et al. (2013) The Influence of Chankanay Zeolites as Feed Additives on the Chemical, Biochemical and Histological Profile of the Rainbow Trout (Oncorhynchus mykiss). J Aquac Res Development 5: 205 doi:10.4172/2155-9546.1000205

Page 4 of 8

good indicator of the nutritional status of fish. The intestine and liver are the most important organs involved in the digestion and absorption of nutrients from food, and therefore, monitoring these organs is considered to be necessary.

The macroscopic structure of fish from the experimental groups did not have marked abnormalities of the internal organs. In macroscopic terms, the liver was not enlarged, the capsule was smooth, and the surface was flat, brown, with a normal consistency and mild hyperemia. A number of authors link the morpho-physiological condition of the liver with feeding [34]. Our histological examination showed that livers of fish from the experimental group maintained their overall body plan, lobes and primary structural components. Radially arranged liver strands made up of polygonal liver cells diverge from the central vein. The cytoplasm of liver cells is round, located in the center of the cell. Clumps of chromatin are stained purple with hematoxylin. Hepatic strands are closely intertwined with the sinusoidal capillaries which look like gaps between strands of hepatic cells when stained. The nuclei of the sinusoidal capillaries' endothelium are elongated, sometimes

\begin{tabular}{|c|c|c|c|c|c|}
\hline \multirow{2}{*}{$\begin{array}{l}\text { Fatty acid composition, } \\
\qquad \mathrm{g} / 100 \mathrm{~g}\end{array}$} & \multirow{2}{*}{$\begin{array}{l}\text { Control group } \\
(n=20)\end{array}$} & \multicolumn{4}{|c|}{ Experimental group } \\
\hline & & $1 \%$ & $2 \%$ & $3 \%$ & $4 \%$ \\
\hline C 12:0 (Lauric acid) & $0,04 \pm 0.03^{a}$ & $0,04 \pm 0.02^{\mathrm{a}}$ & $0,05 \pm 0.02^{\mathrm{a}}$ & $0,05 \pm 0.02^{\mathrm{a}}$ & $0,04 \pm 0.02^{\mathrm{a}}$ \\
\hline C 13:0 (Tridecanoic acid) & $0,02 \pm 0.02^{\mathrm{a}}$ & $0,01 \pm 0.04^{a}$ & $0,03 \pm 0.02^{\mathrm{a}}$ & $0,02 \pm 0.02$ & $0,01 \pm 0.023^{a}$ \\
\hline C 14:0 (Miristic acid) & $3,27 \pm 0.06^{a}$ & $3,85 \pm 0.07^{a}$ & $3,76 \pm 0.03^{a}$ & $3,72 \pm 0.03^{a}$ & $3,45 \pm 0.02^{a}$ \\
\hline C 15:0 (Pentadecanoic acid) & $0,37 \pm 0.03^{a}$ & $0,37 \pm 0.05^{a}$ & $0,37 \pm 0.04^{a}$ & $0,36 \pm 0.05^{a}$ & $0,36 \pm 0.03^{a}$ \\
\hline C 16:0 (Palmitic acid) & $15,99 \pm 0.05^{a}$ & $16,16 \pm 0.08^{a}$ & $16,05 \pm 0.07^{a}$ & $16,22 \pm 0.10^{\mathrm{a}}$ & $15,34 \pm 0.08^{a}$ \\
\hline C 17:0 (Heptadecanoic acid) & $0,68 \pm 0.02^{\mathrm{a}}$ & $0,58 \pm 0.03^{a}$ & $0,53 \pm 0.05^{a}$ & $0,52 \pm 0.02^{\mathrm{a}}$ & $0,48 \pm 0.03^{a}$ \\
\hline C 18:0 (Stearic acid) & $3,42 \pm 0.13^{a}$ & $3,25 \pm 0.02^{\mathrm{a}}$ & $3,44 \pm 0.04^{a}$ & $3,15 \pm 0.04^{a}$ & $3,25 \pm 0.05^{\mathrm{a}}$ \\
\hline C 20:0 (Arachidic acid) & $0,22 \pm 0.03^{a}$ & $0,21 \pm 0.02^{\mathrm{a}}$ & $0,16 \pm 0.02^{\mathrm{a}}$ & $0,23 \pm 0.02^{\mathrm{a}}$ & $0,21 \pm 0.02^{a}$ \\
\hline C 22:0 (Behenic acid) & $1,54 \pm 0.14^{a}$ & $1,26 \pm 0.05^{\mathrm{a}}$ & $1,32 \pm 0.05^{\mathrm{a}}$ & $1,48 \pm 0.05^{\mathrm{a}}$ & $1,53 \pm 0.04^{a}$ \\
\hline C 23:0 (Tricosanoic acid) & $0,04 \pm 0.02^{\mathrm{a}}$ & $0,04 \pm 0.06^{a}$ & $0,03 \pm 0.03^{a}$ & $0,04 \pm 0.02^{\mathrm{a}}$ & $0,04 \pm 0.02^{\mathrm{a}}$ \\
\hline C 24:0 (Lignoceric acid) & $1,35 \pm 0.02^{a}$ & $1,40 \pm 0.03^{a}$ & $1,44 \pm 0.04^{a}$ & $1,25 \pm 0.05^{\mathrm{a}}$ & $1,54 \pm 0.03^{a}$ \\
\hline Total SFAs & 26,94 & 27,17 & 27,18 & 27,04 & 26,25 \\
\hline \multicolumn{6}{|l|}{ Monounsaturated Fatty Acids } \\
\hline C 14:1 (Myristoleic acid) & $0,23 \pm 0.06^{a}$ & $0,23 \pm 0.04^{a}$ & $0,24 \pm 0.03^{a}$ & $0,23 \pm 0.03^{a}$ & $0,21 \pm 0.02^{\mathrm{a}}$ \\
\hline C 16:1 (Palmitoleic acid) & $5,30 \pm 0.02^{\mathrm{a}}$ & $5,29 \pm 0.08^{a}$ & $5,25 \pm 0.05^{\mathrm{a}}$ & $5,36 \pm 0.04^{a}$ & $5,95 \pm 0.02^{\mathrm{a}}$ \\
\hline C $17: 1$ (cis 10 -heptadecenoic acid) & $0,26 \pm 0.06^{a}$ & $0,23 \pm 0.02^{\mathrm{a}}$ & $0,21 \pm 0.02^{\mathrm{a}}$ & $0,23 \pm 0.02^{\mathrm{a}}$ & $0,35 \pm 0.03^{a}$ \\
\hline C 18:1 n9 (Oleic acid) & $20,98 \pm 0.09^{a b}$ & $20,27 \pm 0.11^{\mathrm{ab}}$ & $21,72 \pm 0.10^{\mathrm{ab}}$ & $21,52 \pm 0.07^{\mathrm{ab}}$ & $20,08 \pm 0.08^{\mathrm{ab}}$ \\
\hline C 20:1 (cis -11- eicosenoic acid) & $2,43 \pm 0.02^{\mathrm{a}}$ & $2,41 \pm 0.05^{a}$ & $2,35 \pm 0.04^{\mathrm{a}}$ & $2,41 \pm 0.03^{a}$ & $2,41 \pm 0.02^{\mathrm{a}}$ \\
\hline C 24:1 (Nervonic acid) & $1,46 \pm 0.02^{\mathrm{a}}$ & $1,61 \pm 0.06^{a}$ & $1,52 \pm 0.06^{a}$ & $1,53 \pm 0.02^{\mathrm{a}}$ & $1,48 \pm 0.02^{\mathrm{a}}$ \\
\hline Total MUFAs & 30,66 & 30,04 & 31,29 & 31,28 & 30,48 \\
\hline \multicolumn{6}{|l|}{ Polyunsaturated Fatty Acids } \\
\hline C 18:2 n6 (Linoleic acid) & $11,06 \pm 0.02^{\mathrm{a}}$ & $11,11 \pm 0.02^{\mathrm{a}}$ & $11,24 \pm 0.03^{\mathrm{a}}$ & $11,35 \pm 0.02^{\mathrm{a}}$ & $11,45 \pm 0.03^{\mathrm{a}}$ \\
\hline C 18:3 n6 (y-linolenic acid) & $0,29 \pm 0.03^{b}$ & $0,42 \pm 0.02^{\mathrm{b}}$ & $0,35 \pm 0.02^{\mathrm{b}}$ & $0,28 \pm 0.02^{b}$ & $0,26 \pm 0.02^{b}$ \\
\hline C $18: 3$ n3 (Linolenic acid) & $1,86 \pm 0.02^{a}$ & $1,99 \pm 0.05^{\mathrm{a}}$ & $1,89 \pm 0.04^{a}$ & $1,94 \pm 0.03^{a}$ & $1,86 \pm 0.04^{a}$ \\
\hline C 20:2 (cis-11,14-eicosadienoic acid) & $0,58 \pm 0.02^{b}$ & $0,50 \pm 0.03^{b}$ & $0,45 \pm 0.04^{b}$ & $0,55 \pm 0.04^{b}$ & $0,65 \pm 0.04^{b}$ \\
\hline C $20: 3$ n6 (cis-8,11,14-eicosatrienoic acid) & $0,24 \pm 0.07^{a}$ & $0,23 \pm 0.07^{a}$ & $0,24 \pm 0.07^{a}$ & $0,21 \pm 0.06^{a}$ & $0,23 \pm 0.07^{a}$ \\
\hline C $20: 3$ n3 (cis-11,14,17-eicosatrienoic acid) & $0,58 \pm 0.02^{b}$ & $0,58 \pm 0.02^{\mathrm{b}}$ & $0,51 \pm 0.02^{\mathrm{b}}$ & $0,56 \pm 0.02^{\mathrm{b}}$ & $0,58 \pm 0.02^{b}$ \\
\hline C $20: 4$ n6 (Arachidonic acid) & $0,87 \pm 0.02^{\mathrm{a}}$ & $0,69 \pm 0.07^{a}$ & $0,79 \pm 0.07^{a}$ & $0,71 \pm 0.06^{a}$ & $0,87 \pm 0.07^{a}$ \\
\hline $\begin{array}{c}\text { C } 20: 5 \text { n3 (cis-5,8,11, 14,17-eicosapentaenoic acid) } \\
\text { EPA }\end{array}$ & $3,86 \pm 0.02^{\mathrm{a}}$ & $4,05 \pm 0.03^{a}$ & $4,11 \pm 0.03^{a}$ & $4,12 \pm 0.03^{a}$ & $4,21 \pm 0.03^{a}$ \\
\hline C $22: 2$ (cis 13,16 -docosadienoic acid) & $1,05 \pm 0.06^{b}$ & $1,05 \pm 0.02^{b}$ & $1,02 \pm 0.02^{\mathrm{b}}$ & $1,02 \pm 0.02^{b}$ & $1,06 \pm 0.02^{b}$ \\
\hline $\begin{array}{c}\text { C } 22: 6 \text { n3 (cis-4,7,10,13,16,19-docosahexaenoic } \\
\text { acid) DHA }\end{array}$ & $15,05 \pm 0.02^{\mathrm{a}}$ & $16,09 \pm 0.02^{\mathrm{a}}$ & $15,05 \pm 0.02^{\mathrm{a}}$ & $15,35 \pm 0.02^{\mathrm{a}}$ & $15,34 \pm 0.02^{\mathrm{a}}$ \\
\hline Total PUFAs & 35,44 & 36,71 & 35,65 & 36,09 & 36,51 \\
\hline PUFAs/SFAs & $1,32 \pm 0.02^{a}$ & $1,35 \pm 0.02^{\mathrm{a}}$ & $1,31 \pm 0.05^{\mathrm{a}}$ & $1,33 \pm 0.05^{\mathrm{a}}$ & $1,39 \pm 0.03^{a}$ \\
\hline Ó n6 & $12,46 \pm 0.07^{a}$ & $12,45 \pm 0.06^{a}$ & $12,62 \pm 0.03^{a}$ & $12,55 \pm 0.07^{a}$ & $12,81 \pm 0.08^{a}$ \\
\hline Ó n3 & $21,35 \pm 0.05^{b}$ & $22,71 \pm 0.04^{b}$ & $21,56 \pm 0.05^{b}$ & $21,97 \pm 0.05^{b}$ & $21,99 \pm 0.03^{b}$ \\
\hline $\mathrm{n} 6 / \mathrm{n} 3$ & $0,58 \pm 0.02^{a}$ & $0,55 \pm 0.02^{\mathrm{a}}$ & $0,59 \pm 0.05^{a}$ & $0,57 \pm 0.05^{a}$ & $0,58 \pm 0.03^{a}$ \\
\hline DHA/EPA & $3,90 \pm 0.08^{a}$ & $3,97 \pm 0.08^{a}$ & $3,66 \pm 0.07^{a}$ & $3,73 \pm 0.05^{\mathrm{a}}$ & $3,64 \pm 0.06^{a}$ \\
\hline Unidentified & $6,96 \pm 0.02^{\mathrm{a}}$ & $6,08 \pm 0.02^{\mathrm{a}}$ & $5,88 \pm 0.03^{a}$ & $5,59 \pm 0.02^{a}$ & $6,76 \pm 0.04^{a}$ \\
\hline
\end{tabular}

Table 3: The fatty acids compositions of rainbow trout (control and experimental groups, $\%$ of total fatty acid). 
Citation: Paritova A, Sarsembayeva N, Łozowicka B, Maulanov A, Kuzembekova G, et al. (2013) The Influence of Chankanay Zeolites as Feed Additives on the Chemical, Biochemical and Histological Profile of the Rainbow Trout (Oncorhynchus mykiss). J Aquac Res Development 5: 205 doi:10.4172/2155-9546.1000205

Page 5 of 8

appearing in the lumen of the capillary. Interlobular bile ducts form triads between the liver lobules together with the ramifications of the portal vein and hepatic artery.

The skeletal muscle of the fish is represented by striated muscle tissue (Figure 2). On the longitudinal sections of muscle fibers a strand

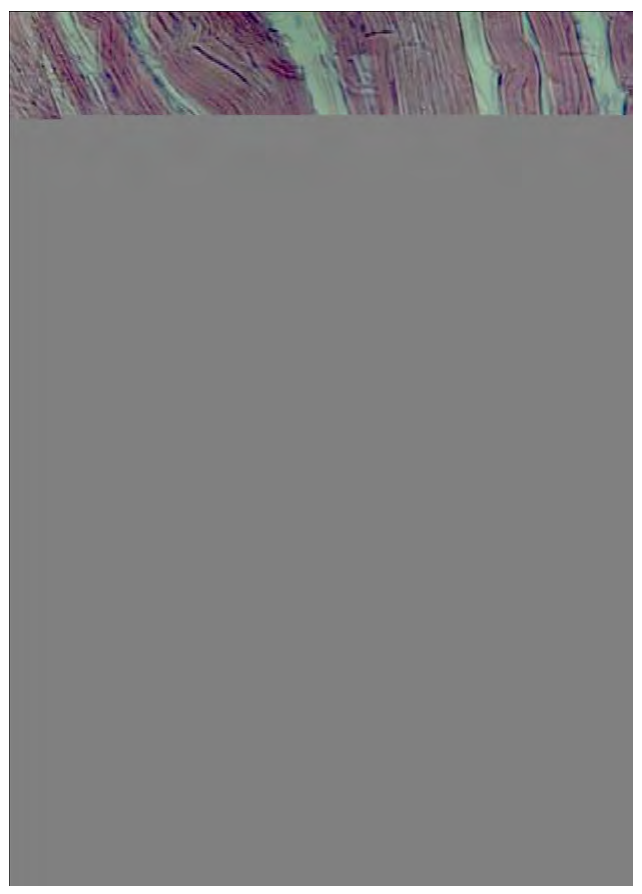

Figure 2: Transversely striated muscle tissue.

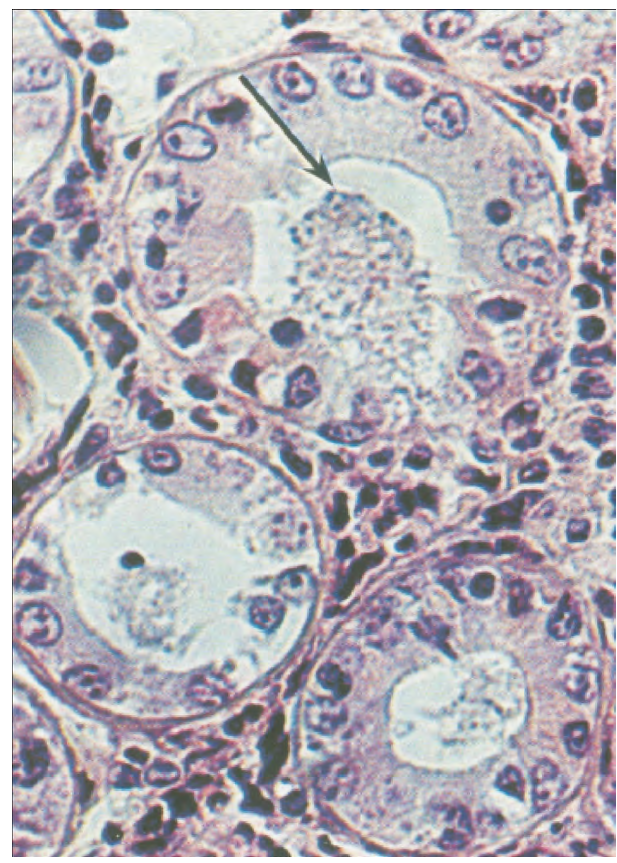

Figure 3: Renal tubules of the kidney of a rainbow trout (the arrow indicates the accumulation of eosinophil protein mass in the lumen of the tubules after hematoxylin and eosin (H\&E) staining). of fiber is visible and has the form of a contour line. There are elongated nuclei with small clumps of chromatin under the sarcolemma on the fiber's periphery. The central part of the fiber is occupied by myofibrils, which give the fiber longitudinal striations that stand out differently in various fibers. The spaces between cross-striated muscle fibers are filled with layers of endomysium.

The addition of zeolites to the daily diet of fish for 63 days led to an increase of the thickness of the mucous membrane of the small intestine in comparison to the control group. The mucous membrane of the large intestine in the control group of fish is slightly thicker than in the experimental group, and the crypts in the mucosa of the experimental group of fish are larger. The ratio of goblet cells to other cells of the mucous membrane in the experimental group was higher than in the control group. As in all mammals, the intestinal wall of a fish consists of three layers. However, fish have no villi on the mucosa, there are only folds instead of them. The mucosa of the small intestine is shown as a single layer of prismatic epithelium, the cells of which are tall and narrow. The nuclei of cells, mainly oval in shape, lie closer to the basal end of the cells. Goblet cells are frequently observed between prismatic cells. Their cytoplasm is filled with mucus, and the nucleus is shifted to the basal part of the cell. The amount of goblet cells in the experimental group is increased compared to the control group.

The kidney is one of the first organs to be affected by contaminants [35]. Histological investigation (Figure 3) shows that in the kidney of the fish fed with $4 \%$ zeolite the wall of the Bowman capsule is present in two layers. The outer layer of the capsule is visible; the nuclei of the cells are extended. The inner leaf of the capsule is difficult to discern, because it is closely fused with a ball of capillaries that grow into the capsule. The epithelial cells of tubules have a cubic shape, and nuclei are round in shape with distinct clumps of chromatin and a relatively large nucleolus. The cytoplasm of cells is cloudy with a hint of dark pink. A brush-shaped rim is well expressed at the apical end of the cells. The convolute tubules pass into a relatively short intercalated part. These are much thinner tubes lined with a low-columnar epithelium with oval nuclei. Their cytoplasm is bright, and there are no brush-type edges at the apical ends of the cells.

Table 1 shows a chemical profile of the muscle tissue of control and experimental groups of fish. Moisture, protein, lipid, and ash contents in the meat of experimental rainbow trout amounted to 73.96, 17.54, 5.46 and $1.44 \%$ on average, respectively. The results of the fish study showed that the use of natural zeolites in the diet of fish does not lead to significant changes of the chemical composition; however, a higher content of protein substances of about $2.73 \mathrm{~g} / 100 \mathrm{~g}$ is observed in the muscle tissue of fish belonging to the experimental group of fish fed with feed with the addition of $4 \%$ zeolite. Lipid and ash content in all groups is nearly at the same level, however the highest values are presented by the group of fish receiving feed with the addition of $4 \%$ zeolite (control group 5.30; 1.43 and experimental with $4 \%-5.50 ; 1.45$ $\mathrm{g} / 100 \mathrm{~g}$, respectively).

The presented values are favorably comparable with published reports on different salmonid species [36]. Also, Gonzalez et al. [37] reported higher lipid content $(6.55 \%)$ and lower protein content $(16.04 \%)$ in rainbow trout (O. mykiss) as compared to the findings of the present study. In the studies of Celik et al. [38] moisture, protein, lipid and ash contents of rainbow trout meat were 1.65, 19.60, 4.43 and $1.36 \%$, respectively. Similar values are presented in studies by Ozden [39]: $76.23,18.57,3.71$ and $1.47 \%$, for moisture, protein, fat and ash, respectively. 
Citation: Paritova A, Sarsembayeva N, Łozowicka B, Maulanov A, Kuzembekova G, et al. (2013) The Influence of Chankanay Zeolites as Feed Additives on the Chemical, Biochemical and Histological Profile of the Rainbow Trout (Oncorhynchus mykiss). J Aquac Res Development 5: 205 doi:10.4172/2155-9546.1000205

Page 6 of 8

\section{Study of amino acid content}

The quality of the fish protein evaluated on the basis of the amino acids contained in it. The most important amino acids are exogenous amino acids, which are indispensible for the human body. The amino acid content ( $\mathrm{g} / 100 \mathrm{~g}$ amino acid) in the rainbow trout from the control and experimental groups has been analyzed, and the results are shown in Table 2. In this study, some amino acids exhibited a significant difference of content between the groups. Differences in the types and amounts of amino acids in fish tissues have been attributed to the location, size of fish, age, food, reproductive status and season [40-43].

The most exogenous amino acids were found in the rainbow trout fed with $4 \%$ zeolite feed $-8.94 \mathrm{~g}$ of these amino acids were found in 100 $\mathrm{g}$ of the muscle tissue. The daily demand for the amino acids required for an adult human weighing $70 \mathrm{~kg}$ is equal to $5.59 \mathrm{~g}$ [44]. The results of the studies indicated that $100 \mathrm{~g}$ of the fish muscle tissue orom each experimental group covered the ingredient's daily demand of an adult human.

A glutamic acid (containing 3.25-3.28\%) was present in the highest amount among the amino acids measured in all the experimental groups. Similar results for the glutamic acid was reported in the rainbow trout (O. mykiss), an Atlantic salmon (Salmo salar), a channel catfish (Ictalurus punctatus) [45], Oreochromis niloticus, Tilapia zilli, Sarotherodon galileaus, Clarias anguillaris, Clarias gariepinus and Heterobranchus longifilis [46], and a Beluga Sturgeon (Huso huso) [47]. Glutamine from muscles serves as an important carrier of ammonia (nitrogen) to the immune system [48].

The most important amino acids in terms of nutritional value that cannot be synthesized by the human body and must be supplied in diet are: lysine, methionine, and cysteine. Histidine is another valuable amino acid for the human body and belongs to the group of relatively exogenous amino acids that are produced in a human body. However under certain conditions, e.g. a rapid growth or a disease, its amount is insufficient, and must be supplied in diet.

A particularly advantageous increase of the content was noted for lysine, methionine, and cysteine in the group of the fish fed with the addition of zeolite. The highest content was noted for the group of the fish fed with the addition of $4 \%$ zeolite.

In this study, the content of the essential amino acids in the rainbow trout fed with RGM-2M enriched with zeolite was higher (8.07-8.94\%) than the content in the control group (7.7\%) (Table 2). The nonessential amino acid content was also higher in the rainbow trout from the experimental groups (9.01-9.69\%) than in the trout from the control group (9.00\%) (Table 2).

These content levels were the evidence that the rainbow trout fed with RGM-2M/zeolite were a very good source of the amino acids. It was significant to note that the rainbow trout contained a broad variety of the amino acids and their isomers, as well as a particularly high proportion of EAA. There were higher levels of the amino acids in the experimental fish than in the control group.

The most significant increases in the experimental groups in comparison to the control group were observed for the leucine and the lysine. The significant decreases were observed for the tryptophan and the glycine.

The proportion of those essential amino acids to the non-essential amino acids was greater for the experimental group (0.89-0.92) than the control group $(0.85)$. In the study, this proportion was greater than it had been stated in other works: it was 0.78 for Huso huso [47], 0.77 for a sea bream (Pagrus major), 0.77 for a mackerel (Scomber japonicus), 0.71 for a mullet (Mugil cephalus), 0.69 for a sardine (Sardina melonosticta), 0.74 for a herring (Clupea pallasi), and 0.75 for a chum salmon (Oncorhynchus keta). Dezhabad et al. [49] had reported that the proportion of the essential amino acids to the non-essential amino acids for the three species: Rutilus frisii, Hypophthalmicthys molitri and Oncorhynchus mykiss, ranged from 1.03 to 1.19.

\section{Study of the fatty acid content}

It is known that the fish meat does not contain significant amounts of the lipids. However, the study of its fatty acid content is of significant interest, not from the perspective of determining its biological value, but as the indicator which points at cell abnormalities in biochemical processes. It was found that the zeolite increased mainly the level of polyunsaturated fatty acids in the fish meat.

The biochemical composition may be affected by the species of the fish, environmental factors, size, age, and diet [41-43,50-52]. The fish can be a source of essential fatty acids [53]. In this study, FA contents (\% of total FAs) in the rainbow trout fed with RGM-2M with zeolite from the experimental and control groups were given in Table 3.

After analysing of the fatty acids it was found that there were higher and lower levels of the fatty acids in the experimental fish than in the control group.

The FA contents of the fish in the control and experimental groups ranged from $26.25 \%$ to $27.37 \%$ of the saturated fatty acids (SFAs), $30.04-31.29 \%$ of monounsaturated acids (MUFAs) and $35.44-36.71 \%$ of PUFAs.

The lipids in the fatty muscle tissue of the trout fed with 2 and 3\% zeolite feed contained the most saturated fatty acids. The majority of monoene acids were contained in the lipids of the muscle tissue of the fish fed with feed with the addition of 2 and $3 \%$ zeolite. The level of SFAs was comparable, and MUFAs was significantly lower than the level observed by Łuczyńska [54]. Most n-6 polyene fatty acids were noted in the muscle tissue of the fish fed with the $1 \%$ zeolite feed. However this content was higher in all the experimental groups in comparison to the control group. Among them, those present in the highest content in the experimental group of the fish were C18:1n9, an oleic acid (OLA, 20,08-21,72 \%), C16:0, a palmitic acid (PAA, 15.34-16.22\%), DHA (15.05-16.09\%), C18:2 a linoleic acid (LIA 11.06-11.45\%), a palmitoleic acid (PLA 5.30-5.69\%), C16:1 EPA (3.86-4.21\%), a stearic acid (STA 3.15-3.44\%), and C14:0, and a myristic acid (MYA, 3.27-3.85\%).

Epidemiological studies showed that an n-3 fatty acid intake is inversely related to cancer, cardiovascular diseases [55], psychiatric disorders [56], asthma [57], bone mineral density [58] and type 2 diabetes [59]. Because of this fact, the polyunsaturated fatty acids (PUFAs) should be separated into the n-3 and n-6 fatty acids. Although the n-3 and n-6 PUFA levels in the two experimental groups (1\% and $3 \%$ zeolite) were higher than in the control group, the difference was statistically significant.

The muscle tissue of the trout fed with $4 \%$ zeolite feed was characterized as the richest source of EPA. The linoleic acid was dominant in the group of n- 6 fatty acids, and DHA and EPA were dominant in the $\mathrm{n}-3$ group. Other researchers have made similar observations $[54,60,61]$.

The proportions of FAs-n3 (21.35\%; $21.56-22.71 \%$ control and experimental groups) were generally higher than those of FAs-n6 
Citation: Paritova A, Sarsembayeva N, Łozowicka B, Maulanov A, Kuzembekova G, et al. (2013) The Influence of Chankanay Zeolites as Feed Additives on the Chemical, Biochemical and Histological Profile of the Rainbow Trout (Oncorhynchus mykiss). J Aquac Res Development 5: 205 doi:10.4172/2155-9546.1000205

Page 7 of 8

(12.46\%; 12.45-12.81\%). The UK Department of Health recommends an ideal $\mathrm{n} 6 / \mathrm{n} 3$ ratio of 4.0 at maximum [62]. Values higher than the maximum value are harmful to health and may promote cardiovascular diseases [63]. In this study, the $\mathrm{n} 6 / \mathrm{n} 3$ ratio was found to be $0.55-0.59$ in all the experimental groups.

The recommended minimum value of the PUFAs/SFAs ratio is 0.45 [62], which is lower than the values of 1.32 and 1.31-1.39 from the control group and the experimental groups treated with RGM-2M and additives. DHA/EPA ratio ranged from 0.72 to 6.89 in some fresh water fish species [64] and it was equal to 1.56 in the rainbow trout [65].

In this study, the ratio of DHA/EPA in the rainbow trout fed with RGM-2M enriched in $1 \%$ zeolite was found to be 3.97 and was greater than in the control group (3.90). In other groups, this ratio was lower and amounted to $3.64-3.73$.

On the basis of the conducted analysis no single correlation could be found between the content of individual fatty acids and the percentage of zeolite's addition to the feed. Undoubtedly, the addition of the zeolite had an influence on the profile of fatty acids in lipids in the muscle tissue of rainbow trout, and it also increased the content of n-3 and n- 6 polyene fatty acids advantageously.

\section{Conclusion}

The nutritive value of the fish and its physiological role as a source of bioactive substances for humans is dependent on the proportions of proteins, fats and mineral substances, the study of the chemical composition of the fish meat is an important part of the veterinarysanitary examination The addition of various amounts of the additive to the fish feed does not only improve the aesthetics of the outer appearance of fish products but also increases their storage life, as well as the content of vitamins, mineral elements, and food materials.

The results of this study confirm that the zeolites have a positive effect on the chemical composition and physical and biochemical features of the meat. A negative effect of clinoptilolite hasn't been determined. From a practical point of view, the rainbow trout $(O$. mykiss) fed on RGM-2M with up to $4 \%$ zeolite contains a higher amount of essential amino acids desirable in a daily diet. This study shows the increase in the level of the polyunsaturated fatty acids. Moreover, using the zeolites as the feed additive for the fish can be a significant part of a comprehensive program to control the fish meat quality.

The introduction of the natural zeolites from the Chankanay deposit into the diet of the fish in the amount of $1-4 \%$ weight of the diet does not cause pathological changes in the liver, muscles and other organs of the fish in the experimental group. Therefore, it has no negative effects on the proteolytic enzyme systems of the fish or on breeding. Our studies show that zeolites are a valuable mineral feed additive of natural origin that promotes the production of the fish meat both qualitatively and quantitatively.

\section{References}

1. Bish D, Ming D (2001) Applications of Natural Zeolites in Water and Wastewater Treatment. Natural Zeolites: Occurrence, Properties, Applications 45: 519-550.

2. Wang S, Zhu Z (2006) Characterisation and Environmental Application of an Australian Natural Zeolite for Basic Dye Removal from Aqueous Solution. J Hazard Mat 136: 946-952.

3. Martin-Kleiner I, Flegar-Mestric Z, Zadro R, Breljak D, Stanovic Janda S, Stojkovic R, Marusic M, Radacic M, Boranic M (2001) The Effect of the Zeolite Clinoptilolite on Serum Chemistry and Haematopoiesis in Mice. Food Chem. Toxicol. 39: 717-727.
4. Papaioannou DS, Kyriakis CS, Alexopoulos C, Tzika ED, Polizopoulou ZS, Kyriakis SC (2004) A Field Study on the Effect of Dietary Use of a ClinoptiloliteRich Tuff, Alone or in Combination with Certain Antimicrobials, on the Health Status and Performance of Weaned, Growing and Finishing Pigs. Res Vet Sci 76: 19-29.

5. Malymin R (2000) Biologic Porous Silica-Type Sorbents in the Prevention of Obstetric Pathology of Cows. Phd Thesis, Lvov (Ukr.).

6. Yarovan N (2008) Effect of Zeolites on the Adaptation Processes of Cows Reports RAAS 2: 43-45.

7. Fethiere R, Miles R, Harms R (1994) The Utilization of Sodium in Sodium Zeolite A by Broilers. Poultry Sci 73: 118-121.

8. Kiaei M, Farkhoy M, Modirsanei M, Rasoulizadeh H (1997) The Effect of Natural Zeolite Extracted in Iran (Clinoptilolite) on Growth Rate, Feed Efficiency and Mortality of the Broiler Chicks. J Facul Vet Med 52: 71-79.

9. Kiaei M, Modirsanei M, Farkhoy M, Taghdiri A (2002) Effects of Diatomite and Natural Zeolite Supplementation on the Performance of Broiler Chicks and Litter Moisture. J Facul Vet Med 57: 19-24.

10. Olver M (1997) Effect of Feeding Clinoptilolite (Zeolite) on the Performance of Three Strains of Laying Eggs. Br Poultry Sci 38: 220-222.

11. Nesic V, Aleksic Z, Dimitrijevic S (2003) The Influence of a Diet of Mixed Feed Containing Zeolite on the Course of Cecal Coccidiosis in Broilers. Acta Vet (Belgrade) 53: 377-383.

12. Gezen S, Eren M, Deniz G (2004) The Effect of Zeolite on Broiler Performance. Indian Vet. J. 81: 411-415.

13. Zedgenizova S, Prosekina O (2004) Some Blood Parameters in Study of Zeolite on the Organism of Hens from Yakut Poultry. Materials of Siberian International Scientific-Practical Conference: Actual Problems of Veterinary Medicine 431-444.

14. Andreeva A, Gadev R (2006) Ural Zeolites - A Source of Macro-And Micronutrients in the Diet of Laying Hens. Application Bio Elementology 12: 20-22.

15. Yezhkov V (2006) The Morphology of Some of Broiler Chickens in the Application of Different Doses of Zeolite-Containing Feed Additives. Proceedings of Kazan State Academy of Veterinary Medicine 190: 34-41.

16. Kuramshina N, Mannapova R, Topuria G, Mannapov A (2007) South-Ural Zeolites - Environmental Safety and Impact on the Body of Birds, Farm Animals. Ufa-Orenburg-Moscow, Bashgau Publishing House.

17. Lumbunov S, Luzbaev K, Alexandrov E (2003) Natural Minerals in Anima Husbandry of Buryatia. Non-Conventional Natural Resources, Innovative Technologies and Products: Digest of Scientific Articles. 6th Publication. 322324.

18. Shambayeva S, Shambayeva M (2006) The Effectiveness of Mukhor-Talinsky Field Zeolites in Feeding Replacement Chicks. Modern Methods for Improving Productivity of Livestock Animals. Proceedings of the Scientific Conference of Technological Faculty of BSAA.119-122.

19. Kudryashov L, Kucheruk S (2008) Effect of Natural Zeolites on Productivity and Meat Quality of Broiler Chicks. Meat Industry 9: 16-19.

20. Sorokina El, Aksiuk IN, Chernysheva ON, Kirpatovskaia NA (2001) Assessment of the Effectiveness of Biologically Active Food Additives Based on Zeolites in Experimental Animals (In Russian). Vopr. Pitan. 70: 35-38.

21. Kuramshina N, Gadev R, Kuramshin E, Latypova G (2006) Environmenta Safety of Mineral Additives in Poultry. Appl. Bioelementol 12: 130-132.

22. Khaustov $\vee(2002)$ Vitamin K4 and Zeolites in Rations for Fattening Ducks Zootechny 10: 18-19.

23. Polyakov A, Buzmakov G, Rassolov S (2009a) Transportation of Carp Larvae Using Zeolite (On Example of Kemerovo Region). Success Modern Science 6: 66-67.

24. Polyakov A, Buzmakov G, Rassolov S (2009b) Use of Zeolite Tuff as a Supplement to the Diet of Carp Fingerlings. Modern High-Tech Technologies 2: $35-37$.

25. Rimar J, Gavalova Z (2002) Utilization of Calcium Formate as an Ingredient in Compound Feed, As Well As a Preservative for Silage Forage. Chemko Strazske 16, 121. 
Citation: Paritova A, Sarsembayeva N, Łozowicka B, Maulanov A, Kuzembekova G, et al. (2013) The Influence of Chankanay Zeolites as Feed Additives on the Chemical, Biochemical and Histological Profile of the Rainbow Trout (Oncorhynchus mykiss). J Aquac Res Development 5: 205 doi:10.4172/2155-9546.1000205

Page 8 of 8

26. Skalicka M, Korenekova B, Makoova Z, Nad P (2002) Effect of Additives on the Selected Poultry Production Indicators. Zbornýk Z Mezdinarodnej Vedeckej Konferencie 237

27. GOST 23481 1979. Poultry Meat. Method of Hystological Analysis 1979-2-7. Gosstandart (GOST) .

28. GOST 19496 1994. Meat. Method of Histological Investigation 1994-6-2. Gosstandart (GOST)

29. GOST R 51604 2000. Meat and Meat Products. Method of Histological Identification of Compositions 2000-512. Gosstandart (GOST)

30. Grethen LH (1979) Animal Tissue Techniques, 4th Ed, WH Freeman Company.

31. AOAC (1980) Official Methods of Analysis 13th Edn. Washington DC Association of Agricultural Chemists

32. FAO/WHO (1973). Ad Hoc Expert Committee, Energy and Protein Requirements. WHO Technical Reports Series No. 522, FAO Nutrition Report Meeting Series No. 52. Geneva: FAO.

33. Aldai N, Osoro K, Barrón L, Najera A (2006) Gas - Liquid Chromatographic Method for Analysing Complex Mixtures of Fatty Acids Including Conjugated Linoleic Acids (Cis9 Trans11 And Trans10 Cis12 Isomers) and Long-Chain (N-3 Or N-6) Polyunsaturated Fatty Acids: Application to the Intramuscular Fat of Beef Meat. Journal of Chromatography A 1110: 133-139.

34. Ostaszewska T, Dabrowski K, Czuminska K, Olech W, Olejniczak M (2005) Rearing of Pikeperch Larvae Using Formulated Diets-First Success With Starter Feeds. Aquaculture Res 36: 1167-1176.

35. Iqbal F, Qureshi I, Ali M (2004) Histopathological Changes in the Kidney of Common Carp, Cyprinus Carpio Following Nitrate Exposure. J Res Sci Teach 15: $411-418$

36. Testi S, Bonaldo A, Gatta P, Badiani A (2006) Nutritional Traits of Dorsal and Central Fillets from Three Farmed Fish Species. Food Chem 98: 104-111.

37. Gonzalez S, Flick G, O'keefe S, Duncan S, Mclean, E, Craig S (2006) Composition of Farmed and Wild Yellow Perch (Perca Flavescens). J. Food Compos. Anal 19: 720-726.

38. Celik M, Gokce MA, Basusta N, Kucukgulmez A, Tasbozan O, Tabakoglu SS (2008) Nutritional Quality of Rainbow Trout (Oncorhynchus Mykiss) Caught from the Ataturk Dam Lake in Turkey. J. Muscle Foods 19: 50-61.

39. Ozden O (2005) Changes in Amino Acid and Fatty Acid Composition During Shelf Life of Marinated Fish. J Sci Food Agr 85: 2015-2020.

40. Polak-Juszczak L, Adamczyk M (2009) Quality and Amino Acid Composition of Protein of Fish from the Vistula Lagoon. Żywność. Nauka. Technologia. Jakość 3: $75-83$.

41. Gokce MA, Tasbozan O, Celik M, Tabakodlu SS (2004) Seasonal Variations in Proximate and Fatty Acid Compositions of Female Common Sole (Solea Solea). Food Chem 88: 419-423.

42. Guler GO, Aktumsek A, Citil OB, Arslan A, Torlak E (2007) Seasonal Variations on Total Fatty Acid Composition of Fillets of Zander (Sander Lucioperca) in Beysehir Lake (Turkey) Food Chem 103: 1241-1246.

43. Kim JD, Lall SP (2000) Amino Acid Composition of Whole Body Tissue of Atlantic Halibut (Hippoglossus Hippoglossus), Yellow tail Flounder (Pleuronectes Ferruginea) and Japanease Flounder (Paralichthys Olivaceus). Aquaculture 187: 367-373.

44. FAO/WHO 1991. Protein Quality Evaluation. Report of the Joint FAO/WHO Expert Consultation. FAO Food and Nutrition Paper 51. Food and Agriculture Organization of the United Nations, Rome.

45. Wilson R, Cowey C (1985) Amino Acid Composition of Whole Body Tissue of Rainbow Trout and Atlantic Salmon. Aquaculture 48: 373-376.

46. Chukwuemeka U (2008) The Fatty and Amino Acids Profiles of Cichlidae and Claridae Finfish Species. Int. J. Food Saf. 10: 18-25.

47. Kenari A, Regenstein J, Hosseini S, Rezaei M, Tahergorabi R, Nazari R, Mogaddasi M, Kaboli S (2009) Amino Acid and Fatty Acid Composition of Cultured Beluga (Huso Huso) of Different Ages. J Aquat Food Prod Tech 18: 245-265.

48. Deutz N, Reijven P, Athanasas G, Soeters P (1992) Postoperative Changes in Hepatic, Intestinal, Splenic and Muscle Fluxes of Amino Acids and Ammonia in Pigs. Clin Sci 83: 607-614.
49. Dezhabad A (2012) Amino Acid Profile of Kutum (Rutilus Frisii), Silver Carp (Hypophthalmicthys Molitrix) and Rainbow Trout (Oncorhynchus Mykiss). Afr J Agr Res 7 : 4845-4847.

50. Bandarra N, Batista I, Nunes M, Empis J, Christie W (1997) Seasonal Changes in Lipid Composition of Sardine (Sardine Pilchardus). J Food Sci 62: 40-42.

51. Ozogul Y, Ahmad J, Hole M, Ozogul F, Deguara S (2006) The Effects of Partial Replacement of Fish Meal by Vegetable Protein Sources in The Diet of Rainbow Trout (Onchorynchus Mykiss) on Post Mortem Spoilage of Fillets. Food Chem 96: 549-561.

52. Tang H, Chen L, Xiao C, Wu T (2009) Fatty Acid Profiles of Muscle from Large Yellow Croaker (Pseudosciaena Crocea R.) of Different Age. Journal of Zhejiang University Science 10: 154-158.

53. Haliloglu HI, Bayır A, Sirkecioglu A, Aras N, Atamanalp M (2004) Comparison of Fatty Acid Composition in Some Tissues of Rainbow Trout (Oncorhynchus Mykiss) Living in Seawater and Freshwater. Food Chem. 86: 55-59.

54. Łuczyńska J, Tońska E, Borejszo Z (2011) Content of Macro-and Microelements and Fatty Acids in Muscles of Salmon (Salmo Salar L.), Rainbow Trout (Oncorhynchus Mykiss Walb.), and Carp (Cyprinus Carpio L.) Żywność. Nauka. Technologia. Jakość 3 : 162-172.

55. Banning M (2005) The Role of Omega-3-Fatty Acids in the Prevention of Cardiac Events. Br J Nurs 14: 503-508.

56. Peet M, Stokes C (2005) Omega-3 Fatty Acids in the Treatment of Psychiatric Disorders. Drugs 65: 1051-1058.

57. Wong K (2005) Clinical Efficacy of N-3 Fatty Acid Supplementation in Patient with Asthma. J Am Diet Assoc 105: 98-105.

58. Weiss L, Barrett-Connor E, Muhlen D (2005) Ratio of n- 6 to n-3 Fatty Acids and Bone Mineral Density in Older Adults: The Rancho Bernardo Study. Am J Clin Nutr 81: 934-938

59. Nettleton J, Katz R (2005) N-3 Long Chain Polyunsaturated Fatty Acids in Type 2 Diabetes: A Review. J Am Diet Assoc 105: 428-440.

60. Halilodlu HI, Aras NM, Yetim H (2002) Comparison of Muscle Fatty Acids of Three Trout Species (Salvelinus Alpinus, Salmo Trutta Fario, Oncorhynchus Mykiss) Raised Under The Same Conditions. Turk. J Vet Anim Sci 26: $1097-$ 1102

61. Kołakowska A, Szczygielski M, Bienkiewicz G, Zienkowicz L (2000) Some of Fish Species as a Source of N-3 Polyunsaturated Fatty Acids. Acta Ichthyologica et Piscatoria 30: 59-70.

62. HMSO (1994) Nutritional Aspects of Cardiovascular Disease (Report on Health and Social Subjects No. 46). London, HMSO.

63. Moreira A, Visentainer J, De Souza N, Matsushita M (2001) Fatty Acids Profile and Cholesterol Contents of Three Brazilian Brycon Freshwater Fishes. J Food Compos Anal 14: 565-574

64. Su XQ, Antonas KN, Li D (2004) Comparison of n-3 Polyunsaturated Fatty Acid Contents of Wild and Cultured Australian Abalone. Int J Food Sci Nutr 2 149-154.

65. Saglik Aslan S, Guven K, Gezgin T, Alpaslan M, Tekinay A (2007) Comparison of Fatty Acid Contents of Wild and Cultured Rainbow Trout Onchorhynchus Mykiss in Turkey. Fish Sci 73: 1195-1198. 